\title{
Efek Leverage Dan Besaran Perusahaan Pada Manajemen Laba Melalui Pengungkapan Social Responsibility
}

\author{
Sofia Prima Dewi* \\ *Faculty of Economics and Business, Tarumanagara University, Jakarta, Indonesia \\ Email address: \\ sofiad@fe.untar.ac.id
}

\begin{abstract}
The purpose of this study is to obtain empirical evidence whether leverage has a positive effect on earnings management, whether the company size and social responsibility disclosure has a negative impact on earnings management, whether the company size has a positive impact on social responsibility disclosure, and whether the social responsibility disclosure can mediate the impact of company size on earnings management. The sampling technique used was purposive sampling and Smart PLS 3.0 was used for data processing. Research during the 2017-2019 period on 72 companies shows that leverage does not have a positive impact on earnings management, company size has a negative impact on earnings management, company size has a positive impact on social responsibility disclosure, social responsibility disclosure has no negative impact on earnings management, and social responsibility disclosure cannot mediate the impact of company size on earnings management.
\end{abstract}

Key words: Earnings Management; Leverage; Company Size; Social Responsibility.

\begin{abstract}
Abstrak: Tujuan penelitian ialah untuk mendapatkan bukti empiris apakah leverage mempunyai efek positif pada manajemen laba, apakah besaran perusahaan dan pengungkapan social responsibility memiliki efek negatif pada manajemen laba, apakah besaran perusahaan memiliki efek positif pada pengungkapan social responsibility, serta apakah pengungkapan social responsibility dapat memediasi efek besaran perusahaan pada manajemen laba. Teknik pengambilan sampel yang digunakan adalah purposive sampling dan Smart PLS 3.0 digunakan untuk pengolahan data. Penelitian selama periode 2017-2019 terhadap 72 perusahaan menunjukkan leverage tidak mempunyai efek positif pada manajemen laba, besaran perusahaan mempunyai efek negatif pada manajemen laba, ukuran perusahaan mempunyai efek positif pada pengungkapan social responsibility, pengungkapan social responsibility tidak mempunyai efek negatif pada manajemen laba, dan pengungkapan social responsibility tidak dapat memediasi efek besaran perusahaan pada manajemen laba.
\end{abstract}

Kata kunci: Manajemen Laba; Leverage; Besaran Perusahaan; Social Responsibility. 


\section{PENDAHULUAN}

Dalam rangka mengambil keputusan ekonomi setiap perusahaan pada umumnya menyusun laporan keuangan. Laporan keuangan yang memiliki karakteristik relevan, andal, dapat dipahami dan dibandingkan merupakan sarana pertanggungjawaban pihak manajemen perusahaan yang tentunya diharapkan dapat meningkatkan kepercayaan bagi para shareholder. Pihak manajemen perusahaan selain berkewajiban meningkatkan kesejahteraan para shareholder ternyata juga berharap kompensasi yang akan diterima nantinya meningkat. Hal ini tentunya akan menimbulkan konflik kepentingan. Dalam menyajikan laporan keuangan, manajemen umumnya memiliki motivasi opportunistic dan motivasi signaling. Selain itu pihak manajemen memiliki informasi lebih baik disbanding dengan pihak shareholder. Ketidakseimbangan informasi dan dua motivasi di atas dapat mendorong terjadinya manajemen laba. Jika ketidakseimbangan informasi semakin besar maka kemungkinan manajemen laba terjadi juga semakin besar. Salah satu upaya meminimalkan masalah konflik kepentingan adalah dengan melakukan pengawasan yang menimbulkan biaya keagenan. Biaya keagenan dapat diminimalkan dengan cara meningkatkan leverage. Peningkatan leverage akan menambah pengawasan terhadap manajemen dan berdampak pada berkurangnya biaya agensi. Leverage adalah aktivitas peminjaman dana guna mendanai kegiatan operasional perusahaan serta meningkatkan keuntungan perusahaan. Tingkat kemudahan peminjaman dana biasanya ditentukan dari ukuran perusahaan. Perusahaan besar pada umumnya memiliki keunggulan dalam hal jalan masuk ke bursa modal guna memperoleh dana. Perusahaan yang memiliki ukuran lebih besar juga lebih diperhatikan oleh masyarakat dan lingkungan dimana perusahaan tersebut beroperasi.

Untuk menjamin keberlangsungan usaha, tujuan perusahaan tentunya tidak lagi hanya memaksimalkan keuntungan para shareholder sebagaimana yang terjadi selama ini, namun perusahaan harus dapat memaksimalkan manfaat bagi para stakeholder. Perusahaan tidak boleh melakukan kegiatan operasional hanya demi kepentingan perusahaan semata, namun juga harus bermanfaat bagi pihak stakeholder baik stakeholder primer maupun stakeholder sekunder. Hal ini dikarenakan tanggungjawab perusahaan tidak lagi hanya berpijak pada nilai perusahaan yang dilihat dari single bottom line (kondisi ekonomi), namun lebih berpijak pada sinergi dari ekonomi, masyarakat atau sosial, dan planet (lingkungan). Apabila kegiatan yang dilakukan perusahaan tidak sesuai dengan harapan masyarakat dan mendapat penolakan dari lingkungan dimana perusahaan beroperasi maka akan terjadi legitimacy gap. Upaya yang bisa dilakukan perusahaan untuk mengurangi terjadinya legitimacy gap adalah dengan pengungkapan social responsibility, yang merupakan media komunikasi antara perusahaan dan masyarakat. Manfaat jangka panjang yang akan diperoleh perusahaan dengan adanya pengungkapan social responsibility adalah peningkatan profitabilitas serta nilai perusahaan, reputasi perusahaan di mata masyarakat menjadi baik, sehingga legitimasi dapat terjaga dengan baik, dan keberlangsungan usaha perusahaan terjamin. Tentunya pengungkapan social responsibility perusahaan ini tidak bisa dilepaskan dari konflik kepentingan. Pada satu sisi, mengungkapkan social responsibility adalah kewajiban perusahaan guna menjaga legitimasi dari masyarakat, namun di sisi lain, pemegang saham tentunya tidak akan 
menyukai penambahan biaya pengungkapan social responsibility yang akan berdampak pada rendahnya laba periode berjalan.

Penelitian mengenai manajemen laba dan social responsibility sudah banyak dilakukan namun terdapat perbedaan hasil penelitian. Penelitian yang dilakukan ialah replikasi penelitian yang dilakukan (Gayatri dan Pria, 2016). Penelitian ini memiliki perbedaan dengan penelitian (Gayatri dan Pria, 2016) dalam hal periode penelitian, dimana penelitian ini menggunakan periode 2017-2019 sedangkan penelitian (Gayatri dan Pria, 2016) menggunakan periode 2012-2014. Perbedaan berikutnya, penelitian (Gayatri dan Pria, 2016) menguji efek besaran perusahaan pada manajemen laba dengan mediasi pengungkapan social responsibility. Peneliti menambahkan variabel leverage dari penelitian (Puspitosari, 2015) sehingga penelitian ini bertujuan mendapatkan bukti empiris mengenai efek leverage pada manajemen laba dan efek besaran perusahaan pada manajemen laba melalui pengungkapan social responsibility.

\section{KAJIAN TEORI}

Agency Theory. Sesuai pernyataan (Jensen dan Meckling, 1976) manajemen sebagai pihak agen berkewajiban meningkatkan kemakmuran shareholder sebagai pihak prinsipal. Di lain sisi, pihak manajemen juga mempunyai harapan untuk dapat meningkatkan kompensasi yang akan diterimanya. Motivasi yang berbeda dari masing-masing pihak akan menimbulkan konflik kepentingan. Pada umumnya menurut (Apriyani dan Pasaribu, 2015) manajemen menyajikan laporan keuangan dengan motivasi oportunistik dan motivasi signaling. Motivasi oportunistik terkait dengan penerimaan kompensasi pihak manajemen berdasarkan kontrak yang disepakati dengan pihak shareholder, sehingga manajemen akan menyajikan laba lebih tinggi dari yang sesungguhnya. Akibatnya kualitas laba menurun serta pengguna laporan keuangan mengalami kerugian. Motivasi signaling terkait dengan kemakmuran para shareholder sehingga manajemen menyajikan laba yang berkualitas guna memberikan sinyal positif kepada para shareholder. Menurut (Pambudi, 2017) pihak manajemen sebagai agen juga memiliki informasi lebih baik dibandingkan dengan pihak shareholder sebagai prinsipal. Adanya ketidakseimbangan informasi dan dua motivasi di atas dapat mendorong terjadinya manajemen laba.

Stakeholder Theory. Menurut (Freeman dan McVea, 2001) pada stakeholder theory, perusahaan tidak dapat melakukan kegiatan operasional hanya demi kepentingan perusahaan semata, namun juga wajib memberikan manfaat kepada pihak stakeholder yaitu individu atau kelompok yang dipengaruhi oleh atau dapat memengaruhi pencapaian tujuan perusahaan. Tujuan perusahaan yang semula hanya memaksimalkan keuntungan para shareholder sekarang tujuan perusahaan adalah memaksimalkan manfaat bagi para stakeholder. Menurut (Parmar et al., 2010) semua stakeholder harus diperlakukan sama. Stakeholder theory menyatakan bahwa perusahaan memiliki tanggungjawab kepada para stakeholder. Salah satu wujud tanggungjawab tersebut adalah dengan melakukan pengungkapan social responsibility. Dasar pemikiran perusahaan wajib memiliki kepedulian sosial dan lingkungan ialah perusahaan selayaknya mengembalikan sebagian dari keuntungan yang sudah diperoleh kepada masyarakat dan lingkungan dimana perusahaan beroperasi, mengingat perusahaan sudah mendapatkan keuntungan dari adanya 
pemanfaatan terhadap suatu sumber daya. Menurut (Erawati et al., 2018) stakeholder berdasarkan karakteristiknya terdiri dari stakeholder utama dan stakeholder pendukung. Stakeholder utama yaitu pihak yang berinteraksi secara langsung dengan perusahaan, yang tanpanya perusahaan tidak dapat mempertahankan keberlangsungan usahanya. Yang termasuk stakeholder utama adalah karyawan, pelanggan, pemasok, serta pemodal (pemegang saham dan kreditur). Stakeholder pendukung yaitu pihak yang tidak berinteraksi secara langsung dengan perusahaan, tetapi keberadaan perusahaan dipengaruhi oleh kekuatan dan kepentingan stakeholder pendukung. Yang termasuk stakeholder pendukung adalah semua stakeholder yang tidak termasuk dalam stakeholder primer, contohnya aktivis lingkungan, masyarakat, media masa, dan pemerintah.

Legitimacy Theory. Menurut (Guthrie et al., 2006) perusahaan memiliki hubungan kontrak sosial dan akan berusaha melakukan kegiatan operasional sesuai dengan harapan masyarakat dan lingkungan dimana perusahaan beroperasi agar tidak terjadi legitimacy gap. Menurut (Arowoshegbe dan Emmanuel, 2016) tanggungjawab perusahaan tidak lagi hanya berpijak pada nilai perusahaan yang dilihat dari single bottom line (kondisi ekonomi), namun lebih berpijak pada yaitu sinergi dari ekonomi, masyarakat atau sosial, serta planet (lingkungan). Menurut (Lindawati dan Puspita, 2015) perusahaan dapat meminimalkan legitimacy gap dengan cara membuka komunikasi dengan masyarakat melalui pengungkapan social responsibility. Di satu sisi, melalui pengungkapan social responsibility maka nilai serta reputasi perusahaan akan meningkat, legitimasi dari masyarakat tetap terjaga, dan keberlangsungan usaha perusahaan terjamin. Di sisi lain, pengungkapan social responsibility memerlukan biaya tambahan yang tentunya akan mengurangi laba tahun berjalan dan membuat para stakeholder tidak menyukai pengungkapan social responsibility.

Manajemen Laba. Menurut (Ghazali et al., 2015) usaha yang dilakukan perusahaan guna mengelabuhi para stakeholder dengan cara mengubah informasi laporan keuangan sehingga kinerja dan kondisi keuangan perusahaan terlihat lebih baik dari yang sesungguhnya disebut manajemen laba. Tindakan oportunis ini tentunya menguntungkan pihak manajemen perusahaan namun merugikan para stakeholder terutama dalam hal pengambilan keputusan investasi. Manajemen laba muncul karena ada celah dalam akuntansi yang berbasis akrual dimana metode akuntansi yang dibutuhkan dapat dipilih oleh perusahaan sepanjang metode tersebut tidak melenceng dari standar akuntansi keuangan yang berlaku. Menurut (Panjaitan dan Muslih, 2019) motivasi manajemen perusahaan melakukan manajemen laba ada tiga. Pertama yaitu hipotesis rencana bonus yang membahas hubungan keagenan antara manajemen dan pemilik. Prestasi manajemen perusahaan biasanya dikaitkan dengan laba yang diperoleh. Apabila manajemen bisa memperoleh laba yang besar maka bonus yang besar bisa diperoleh, demikian juga sebaliknya. Oleh karena itu manajemen akan berusaha keras untuk meninggikan laba demi mendapatkan bonus yang besar. Cara yang dilakukan manajemen perusahaan adalah dengan mengubah laba di masa depan ke laba di masa kini sehingga laba periode berjalan tinggi dan manajemen memperoleh bonus yang besar. Kedua yaitu hipotesis biaya politik yang membahas hubungan keagenan antara manajemen dan pemerintah. Perusahaan yang memiliki laba tinggi dapat menarik perhatian pihak eksternal yang berdampak pada 
tingginya biaya politik. Cara yang dilakukan manajemen perusahaan adalah menangguhkan laba masa kini ke laba masa depan sehingga laba periode berjalan rendah dan biaya politik bisa diminimalkan. Ketiga yaitu hipotesis perjanjian hutang yang membahas hubungan keagenan antara manajemen dan kreditur. Kemungkinan risiko gagal bayar perusahaan tinggi apabila rasio leverage tinggi. Perusahaan akan sulit memperoleh tambahan dana dari pihak kreditor dan ada kemungkinan perusahaan bisa tidak memenuhi perjanjian hutang. Pelanggaran terhadap perjanjian hutang bisa menimbulkan biaya dan menghambat kerja manajemen. Oleh karena itu, guna memenuhi perjanjian hutang, perusahaan akan menggunakan metode akuntansi yang bisa meningkatkan laba. Hal ini bertujuan untuk mengelabuhi seolah-olah perusahaan memiliki kinerja yang baik dan perusahaan dapat mengurangi, menunda, atau bahkan menghindari pelanggaran perjanjian hutang.

Leverage. Menurut (Saragih dan Sembiring, 2019) leverage (debt to equity ratio) menunjukkan risiko kondisi keuangan yang dihadapi oleh perusahaan. Semakin besar risiko kondisi keuangan maka ketidakpastian laba masa depan akan meningkat. Dalam mengambil keputusan investasi, pihak investor tidak menyukai ketidakpastian laba masa depan. Agar laba terlihat stabil, perusahaan biasanya termotivasi melakukan manajemen laba. Menurut (Putriana et al., 2018) leverage yang diproksikan dengan debt to equity ratio adalah kemampuan perusahaan dalam melunasi hutang dengan ekuitas yang dimiliki jika perusahaan sampai dilikuidasi, sekaligus menilai seberapa besar ekuitas perusahaan dibiayai oleh hutang. Menurut (Astuti et al., 2017) penggunaan hutang yang terlalu tinggi akan membuat posisi perusahaan dalam keadaan bahaya, sehingga perusahaan harus memikirkan sumber dana mana yang dapat digunakan untuk melunasi hutang agar tidak memicu terjadinya manajemen laba.

Besaran Perusahaan. (Wufron, 2017) menjelaskan bahwa cerminan besaran perusahaan adalah besar kecilnya suatu perusahaan. Menurut (Tan dan Hadi, 2020) besaran perusahaan dikelompokkan menjadi perusahaan kecil, sedang, dan besar berdasarkan ratarata total penjualan atau total penjualan dan total aset atau rata-rata total aset. Menurut (Saragih dan Sembiring, 2019) besaran perusahaan yang besar memiliki keunggulan dibandingkan dengan ukuran perusahaan yang kecil, yaitu dalam kemudahan memperoleh dana dari bursa efek, kekuatan tawar menawar dalam kontrak keuangan, dan perolehan laba.

Pengungkapan Social Responsibility. Menurut (Mahrani dan Soewarno, 2018) social responsibility adalah bentuk tanggungjawab perusahaan atas keputusan yang diambil dan aktivitas yang dilakukan terhadap lingkungan dan masyarakat, terlihat dalam bentuk perilaku yang etis dan transparan, yang sesuai dengan pembangunan yang berkelanjutan dan kesejahteraan masyarakat, yang sejalan dengan harapan stakeholder, norma dan hukum yang berlaku, dan merupakan satu kesatuan dengan perusahaan. Di Indonesia, social responsibility bukan hanya merupakan tanggungjawab namun juga merupakan kewajiban. Pengungkapan wajib dilakukan di laporan tahunan perusahaan sesuai peraturan pemerintah yang berlaku. Standar pelaporan yang umum dikenal dan sudah diakui oleh 
perusahaan di seluruh dunia untuk mengimplementasikan social responsibility adalah Global Reporting Initiative.

Penelitian Terdahulu. (Aissyah et al., 2020) serta (Alexander dan Palupi, 2020) menyatakan bahwa leverage berdampak positif pada manajemen laba, sementara (Puspitosari, 2015) menyatakan bahwa leverage tidak berdampak positif pada manajemen laba. (Wilson dan Prasetyo, 2020) menyatakan bahwa leverage berdampak negatif pada manajemen laba, sementara (Putriana et al., 2018) menyatakan bahwa leverage tidak berdampak negatif pada manajemen laba.

(Uwuigbe et al., 2015), dan (Aissyah et al., 2020) menyatakan bahwa besaran perusahaan berdampak positif pada manajemen laba, sementara (Alexander dan Palupi, 2020) serta (Wilson dan Prasetyo, 2020) menyatakan bahwa besaran perusahan tidak berdampak positif pada manajemen laba. (Gayatri dan Pria, 2016) serta (Halim et al., 2020) menyatakan bahwa besaran perusahaan berdampak negatif pada manajemen laba, sementara (Puspitosari, 2015), (Bassiouny, 2016), dan (Surya, 2018) menyatakan bahwa besaran perusahaan tidak berdampak negatif pada manajemen laba.

(Gayatri dan Pria, 2016), (Sumaryono dan Asyik, 2017), (Erawati et al., 2018), (Surya, 2018), dan (Aziz et al., 2021) menyatakan bahwa besaran perusahaan berdampak positif pada pengungkapan social responsibility, sementara (Zulhaimi dan Nuraprianti, 2019) menyatakan bahwa besaran perusahaan tidak berdampak positif pada pengungkapan social responsibility. (Yunina dan Eftiana, 2017) menyatakan bahwa besaran perusahaan berdampak negatif pada pengungkapan social responsibility, sementara (Saragih dan Sembiring, 2019) serta (Kurniawan dan Yuniarta, 2020) menyatakan bahwa besaran perusahan tidak berdampak negatif pada pengungkapan social responsibility.

(Mahrani dan Soewarno, 2018), serta (Halim et al., 2020) menyatakan bahwa pengungkapan corporate social responsibility berdampak positif pada manajemen laba, sementara (Putriana et al., 2018), (Surya, 2018), dan (Kalbuana et al., 2020) menyatakan bahwa pengungkapan social responsibility tidak berdampak positif pada manajemen laba. (Gayatri dan Pria, 2016) menyatakan bahwa pengungkapan social responsibility berdampak negatif pada manajemen laba, sementara (Alexander dan Palupi, 2020) menyatakan bahwa pengungkapan social responsibility tidak berdampak negatif pada manajemen laba. (Gayatri dan Pria, 2016) serta (Surya, 2018) menyatakan bahwa pengungkapan social responsibility dapat memediasi dampak besaran perusahaan pada manajemen laba.

Pengembangan Hipotesis. Efek Leverage Pada Manajemen Laba. Menurut (Aissyah et al., 2020) leverage yang diproksikan dengan debt to equity ratio ialah perbandingan antara total hutang dan total ekuitas. Menurut (Purnama, 2017) semakin tinggi leverage, semakin tinggi perusahaan menghadapi risiko membayar hutang ke pihak kreditur, dan semakin tinggi pula pihak investor menanggung risiko. Pihak kreditur tentunya berharap perusahaan dapat mengembalikan hutang sedangkan pihak investor berharap tingkat keuntungan akan semakin tinggi dengan adanya peningkatan leverage. Untuk menjaga kepercayaan kreditur dan memenuhi harapan investor, pihak manajemen akan cenderung terpicu melakukan manajemen laba. 
Efek Besaran Perusahaan Pada Manajemen Laba. Menurut (Saragih dan Sembiring, 2019) perusahaan yang memiliki ukuran besar memiliki kegiatan operasional yang lebih luas dan kompleks serta stakeholder yang lebih banyak sehingga biasanya akan mendapatkan perhatian atau sorotan lebih banyak dari masyarakat dibandingkan perusahaan berukuran kecil. Menurut (Aissyah et al., 2020) perusahaan yang mendapat perhatian atau sorotan lebih dari masyarakat akan berusaha menjaga kestabilan kinerja dan kondisi keuangan perusahaan. Menurut (Surya, 2018) bila dibandingkan dengan perusahaan kecil, maka tekanan untuk menyajikan laporan keuangan yang lebih akurat dan dapat dipercaya lebih tinggi di perusahaan besar. Oleh karenanya, perusahaan berukuran besar akan menyajikan laporan keuangan dengan hati-hati dan meminimalkan tindakan manajemen laba.

Efek Besaran Perusahaan Pada Pengungkapan Social Responsibility. Menurut (Trijaya dan Riwandari, 2017) perusahaan berukuran besar tidak terlepas dari tekanan politis. Salah satu usaha untuk mengurangi biaya politis adalah melalui pengungkapan social responsibility. Perusahaan dengan ukuran besar mempunyai biaya keagenan yang lebih besar dibandingkan perusahaan kecil. Untuk mengurangi biaya keagenan, perusahaan berukuran besar akan melakukan pengungkapan social responsibility yang lebih luas. Menurut (Saragih dan Sembiring, 2019) perusahaan besar mempunyai jumlah stakeholder yang lebih banyak. Pihak stakeholder memerlukan informasi mengenai aktivitas yang dilakukan oleh perusahaan dan salah satu upaya yang paling efisien guna memberikan informasi kepada para stakeholder adalah dengan melakukan pengungkapan social responsibility. Menurut (Erawati et al., 2018) luasnya pengungkapan informasi dalam laporan tahunan dipengaruhi oleh besaran perusahaan. Biasanya perusahaan besar mempunyai sumber daya yang besar serta aktivitas operasi yang banyak dan kompleks. Umumnya perusahaan besar mendapatkan perhatian atau sorotan lebih dari masyarakat dan mempunyai tekanan untuk mengungkapkan informasi lebih banyak dibandingkan perusahaan kecil termasuk informasi mengenai pengungkapan social responsibility yang ada di laporan tahunan.

Efek Pengungkapan Social Responsibility Pada Manajemen Laba. Umumnya perusahaan menginginkan hubungan jangka panjang dengan para stakeholder, dan untuk itu perusahaan akan berusaha melakukan pengungkapan social responsibility karena dengan adanya pengungkapan ini, maka profitabilitas dan reputasi perusahaan akan meningkat, legitimasi dari masyarakat tetap terjaga, dan keberlangsungan usaha perusahaan akan terjamin. Menurut (Ricardo dan Faisal, 2015) perusahaan yang berkomitmen melakukan pengungkapan social responsibility akan memperoleh legitimasi dari masyarakat dan lingkungan dimana perusahaan beroperasi. Untuk mempertahankan legitimasi tersebut, perusahaan akan meminimalkan tindakan manajemen laba. Menurut (Rahmawardani dan Muslichah, 2020) perusahaan yang lebih banyak melakukan pengungkapan social responsibility akan meminimalkan manajemen laba. Pengungkapan social responsibility menunjukkan transparansi dalam semua aspek bisnis perusahaan. Pihak stakeholder akan menerima informasi lebih banyak mengenai aktivitas perusahaan dengan adanya pengungkapan ini. Tentunya hal ini akan mengurangi asimetri informasi dan membuat para stakeholder percaya kepada perusahaan. Untuk mempertahankan 
kepercayaan para stakeholder, maka manajemen akan meminimalkan tindakan manajamen laba.

Efek Besaran Perusahaan Pada Manajemen Laba Melalui Pengungkapan Social Responsibility. Menurut (Surya, 2018) perusahaan besar akan melakukan pengungkapan social responsibility yang lebih luas. Perusahaan berukuran besar melakukan pengungkapan social responsibility guna memperoleh legitimasi dari lingkungan dan masyarakat dimana perusahaan beroperasi. Menurut (Gayatri dan Pria, 2016) legitimasi dari lingkungan dan masyarakat dimana perusahaan beroperasi sangat penting bagi perkembangan perusahaan di masa depan. Untuk menjaga legitimasi tersebut, manajemen cenderung meminimalkan tindakan manajemen laba.

Penelitian ini memiliki model sebagai berikut:

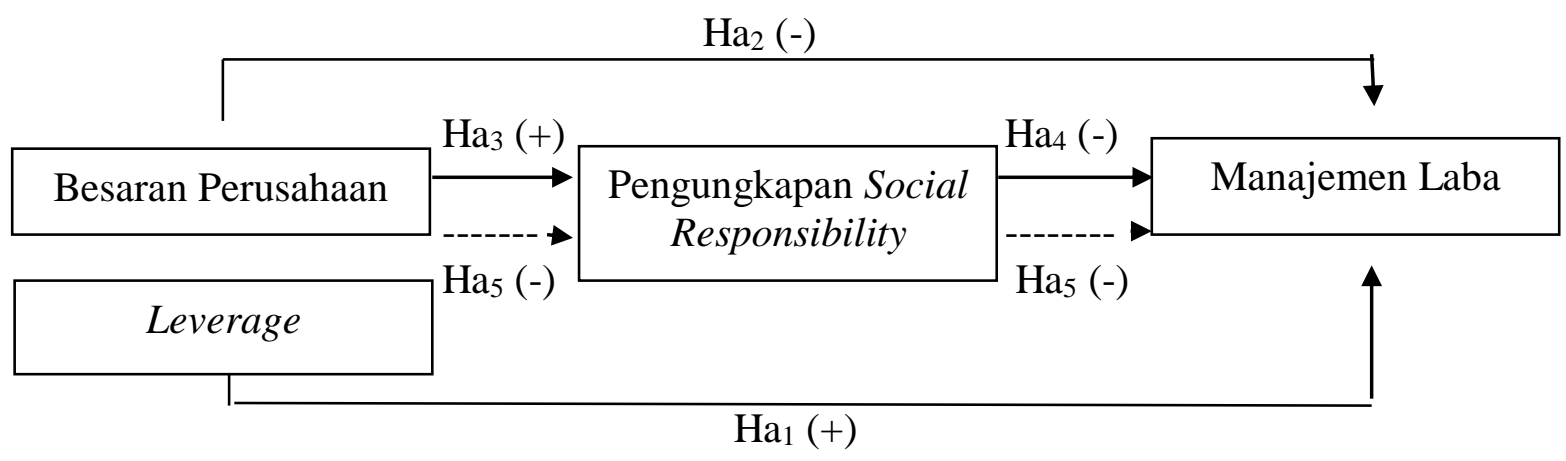

Gambar 1. Model Penelitian

Keterangan:

$\longrightarrow \quad=$ Efek Langsung

$\rightarrow=$ Efek Tidak Langsung

Perumusan hipotesis berdasarkan model penelitian dan penjelasan di atas adalah:

$\mathrm{Ha}_{1}$ : Leverage mempunyai efek positif pada manajemen laba.

$\mathrm{Ha}_{2}$ : Besaran perusahaan mempunyai efek negatif pada manajemen laba.

$\mathrm{Ha}_{3}$ :Besaran perusahaan mempunyai efek positif pada pengungkapan social responsibility.

$\mathrm{Ha}_{4}$ : Pengungkapan social responsibility mempunyai efek negatif pada manajemen laba.

Ha5: Pengungkapan social responsibility dapat memediasi efek besaran perusahaan pada manajemen laba.

\section{METODOLOGI}

Populasi dan Sampel. Seluruh perusahaan manufaktur yang terdaftar secara konsisten di Bursa Efek Indonesia selama periode 2017-2019 digunakan sebagai populasi. Sampel dipilih dengan menggunakan teknik purposive sampling, dimana kriterianya ialah: (1) Perusahaan tidak mengalami kerugian, (2) Laporan tahunan diterbitkan secara konsisten, dan (3) Laporan keuangan disajikan dengan menggunakan mata uang Rupiah. 
Berdasarkan kriteria tersebut, maka diperoleh sampel 72 perusahaan dan dengan tiga periode penelitian yaitu dari peiode 2017-2019 maka diperoleh 216 data.

Teknik Pengumpulan Data. Masing-masing data perusahaan manufaktur di Bursa Efek Indonesia selama periode 2017-2019 dikumpulkan. Data berupa laporan keuangan serta laporan tahunan diolah dengan Smart PLS 3.0. Smart PLS 3.0 digunakan untuk menghitung varibel mediasi secara langsung, karena dalam penelitian ini terdapat satu variabel mediasi yaitu pengungkapan social responsibility. Analisis terhadap efek tidak langsung dapat dilihat dari hasil olah data specific indirect effect.

Operasionalisasi Variabel. Manajemen laba sebagai variabel endogen, variabel eksogen yaitu leverage dan besaran perusahaan, serta variabel mediasi adalah pengungkapan social responsibility. Sesuai penelitian (Nurhandono dan Firmansyah, 2017) manajemen laba yang diberi simbol DA diukur dengan menghitung nilai diskresioner akrual menggunakan model (Kothari et al., 2005) dimana rumusnya adalah:

$$
\text { DAit }=\frac{\text { TAit }}{\text { Ait }-1}-\text { NDAit }
$$

Keterangan:

DAit

TAit

NDAit

Ait-1

$$
\begin{aligned}
& =\text { Diskresioner akrual perusahaan i dalam periode } \mathrm{t} \\
& =\text { Total akrual perusahaan } \mathrm{i} \text { dalam periode } \mathrm{t} \\
& =\text { Non diskresioner akrual perusahaan } \mathrm{i} \text { dalam periode } \mathrm{t} \\
& =\text { Total aset perusahaan } \mathrm{i} \text { dalam periode sebelumnya }
\end{aligned}
$$

Menurut (Ahmar et al., 2016) diskresioner akrual mengandung kelemahan yaitu mengabaikan kinerja perusahaan. Menurut (Suyono, 2017) guna mengukur manajemen laba lebih akurat maka di model (Kothari et al., 2005) dalam menghitung diskresioner akrual ditambahkan perubahan return on asset untuk mengontrol kinerja perusahaan. Sesuai penelitian (Puspitosari, 2015) leverage yang diberi simbol DER dihitung dengan rumus total hutang dibagi total ekuitas. Besaran perusahaan yang diberi simbol UP diukur dengan cara melakukan logaritma natural total aset sesuai penelitian Gayatri dan Pria (2016). Sesuai penelitian (Mahrani dan Soewarno, 2018) pengungkapan social responsibility yang diberi simbol CSR dihitung dengan cara total item informasi sosial yang diungkapkan perusahaan dibagi total item informasi sosial yang harus diungkapkan oleh perusahaan sesuai dengan index Global Reporting Initiative. Total item informasi sosial yang harus diungkapkan adalah 91 item. Skor 1 diberikan apabila item diungkapkan dan skor 0 diberikan apabila item tidak diungkapkan. Jumlah item informasi sosial yang diungkapkan perusahaan dapat dilihat di laporan tahunan perusahaan pada tahun yang bersangkutan. Rumus untuk mencari pengungkapan social responsibility sesuai penelitian (Mahrani dan Soewarno, 2018) adalah:

$$
\text { CSRit }=\frac{\text { Total Value of }{ }^{\prime \prime} 1^{"}}{\text { Number of Item Global Reporting Initiative }}
$$


Berikut adalah operasionalisasi variabel (Tabel 1).

Tabel 1. Operasionalisasi Variabel

\begin{tabular}{|c|c|c|c|}
\hline Variabel & Proksi & Skala & Sumber \\
\hline Manajemen Laba & DAit $=\frac{\text { TAit }}{\text { Ait }-1}-$ NDAit & Rasio & $\begin{array}{l}\text { Nurhandono dan } \\
\text { Firmansyah } \\
\text { (2017) }\end{array}$ \\
\hline Leverage & DERit $=\frac{\text { Total Hutang }}{\text { Total Ekuitas }}$ & Rasio & Puspitosari (2015) \\
\hline $\begin{array}{c}\text { Besaran } \\
\text { Perusahaan }\end{array}$ & UPit $=$ Ln Total Aset & Rasio & $\begin{array}{l}\text { Gayatri dan Pria } \\
\text { (2016) }\end{array}$ \\
\hline $\begin{array}{l}\text { Pengungkapan } \\
\quad \text { Social } \\
\text { Responsibility }\end{array}$ & CSRit $=\frac{\text { Total Value of " } 1 "}{\text { Number of Item Global Reporting Initiative }}$ & Rasio & $\begin{array}{c}\text { Mahrani dan } \\
\text { Soewarno (2018) }\end{array}$ \\
\hline
\end{tabular}

\section{HASIL DAN PEMBAHASAN}

Statistik Deskriptif. Berikut adalah statistik deskriptif masing-masing variabel (Tabel 2).

Tabel 2. Statistik Deskriptif

\begin{tabular}{lcccc}
\hline & $\begin{array}{c}\text { Nilai } \\
\text { Terendah }\end{array}$ & $\begin{array}{c}\text { Nilai } \\
\text { Tertinggi }\end{array}$ & $\begin{array}{c}\text { Nilai Rata- } \\
\text { Rata }\end{array}$ & Standar Deviasi \\
\hline DER & 0,071 & 5,443 & 0,839 & 0,804 \\
UP & 25,935 & 33,495 & 28,696 & 1,530 \\
CSR & 0,066 & 0,571 & 0,234 & 0,089 \\
DA & $-0,004$ & 0,014 & 0,001 & 0,002 \\
\hline
\end{tabular}

Nilai terendah leverage (DER) yaitu 0,071 , nilai tertinggi yaitu 5,443, nilai rata-rata yaitu 0,839 , dan nilai standar deviasi yaitu 0,804 . Artinya leverage memiliki data yang tidak bervariasi. Nilai terendah besaran perusahaan (UP) adalah sebesar 25,935, nilai tertinggi sebesar 33,495, nilai rata-rata yaitu 28,696, dan nilai standar deviasi yaitu 1,530. Artinya besaran perusahaan memiliki data yang tidak bervariasi. Nilai terendah pengungkapan social responsibility (CSR) yaitu 0,066, nilai tertinggi yaitu 0,571 , nilai rata-rata yaitu 0,234 , dan nilai standar deviasi yaitu 0,089. Artinya pengungkapan social responsibility memiliki data yang tidak bervariasi. Nilai terendah manajemen laba (DA) yaitu $-0,004$, nilai tertinggi yaitu 0,014 , nilai rata-rata yaitu 0,001 , dan nilai standar deviasi yaitu 0,002. Artinya manajemen laba memiliki data yang bervariasi.

Uji Kolinearitas. Berikut ialah hasil uji kolinearitas (Tabel 3). 
Tabel 3. Hasil Uji Kolinearitas

\begin{tabular}{lcl}
\hline Variabel & VIF & Keterangan \\
\hline DER $\rightarrow$ DA & 1,017 & Tidak terdapat kolinearitas \\
UP $\rightarrow$ CSR & 1,000 & Tidak terdapat kolinearitas \\
UP + CSR $\rightarrow$ DA & 1,487 & Tidak terdapat kolinearitas \\
UP & 1,505 & Tidak terdapat kolinearitas \\
CSR & & \\
\hline
\end{tabular}

Hasil uji kolinearitas menunjukkan nilai $\mathrm{VIF} \leq 5$, artinya tidak ada kolinearitas pada model regresi.

Effect Size. Berikut ialah hasil uji effect size $\left(\mathrm{f}^{2}\right)$ (Tabel 4).

Tabel 4. Hasil Uji Effect Size (f²)

\begin{tabular}{lcc}
\hline & $\mathbf{f}^{2}$ & Effect Size \\
\hline $\mathrm{DER} \rightarrow$ DA & 0,089 & Lemah \\
$\mathrm{UP} \rightarrow$ DA & 0,011 & Tidak berarti \\
$\mathrm{UP} \rightarrow$ CSR & 0,487 & Kuat \\
$\mathrm{CSR} \rightarrow$ DA & 0,001 & Tidak berarti \\
\hline
\end{tabular}

Hasil uji $\mathrm{f}^{2}$ menunjukkan nilai effect size $\left(\mathrm{f}^{2}\right)$ leverage (DER) terhadap manajemen laba (DA) adalah sebesar 0,089 yang artinya efek leverage (DER) terhadap manajemen laba (DA) adalah lemah. Nilai effect size ( $\mathrm{f}^{2}$ ) besaran perusahaan (UP) terhadap manajemen laba (DA) adalah sebesar 0,011 yang artinya efek besaran perusahaan (UP) terhadap manajemen laba (DA) adalah tidak berarti. Nilai effect size $\left(\mathrm{f}^{2}\right)$ besaran perusahaan (UP) terhadap pengungkapan social responsibility (CSR) adalah sebesar 0,487 yang artinya efek besaran perusahaan (UP) terhadap pengungkapan social responsibility (CSR) adalah kuat. Nilai effect size $\left(\mathrm{f}^{2}\right)$ pengungkapan social responsibility (CSR) terhadap manajemen laba (DA) adalah sebesar 0,001 yang artinya efek pengungkapan social responsibility (CSR) terhadap manajemen laba (DA) adalah tidak berarti.

Adjusted $\mathbf{R}^{2}$. Berikut ialah hasil uji Adjusted $\mathrm{R}^{2}$ (Tabel 5).

Tabel 5. Hasil Uji Adjusted $\mathrm{R}^{2}$

\begin{tabular}{lcc}
\hline Variabel & Adjusted $\mathbf{R}^{\mathbf{2}}$ & Keterangan \\
\hline CSR & 0,324 & Sedang \\
DA & 0,083 & Lemah \\
\hline
\end{tabular}

Hasil uji Adjusted $\mathrm{R}^{2}$ menunjukkan nilai $R$-square untuk pengungkapan social responsibility (CSR) sebesar 0,324. Artinya pengaruh besaran perusahaan (UP) terhadap pengungkapan social responsibility (CSR) sedang. Pada penelitian ini sebanyak 32,4\% pengungkapan social responsibility (CSR) bisa dijelaskan oleh besaran perusahaan (UP), 
sementara 67,6\% dijelaskan oleh variabel lain di luar model penelitian. Nilai $R$-square untuk manajemen laba (DA) sebesar 0,083. Artinya pengaruh leverage (DER) dan besaran perusahaan (UP) terhadap manajemen laba (DA) lemah karena sebanyak 8,3\% manajemen laba (DA) pada penelitian ini bisa dijelaskan oleh pengaruh leverage (DER) dan besaran perusahaan (UP), sementara 91,7\% dijelaskan oleh variabel lain di luar model penelitian.

Hasil Uji Hipotesis. Berikut ialah hasil uji hipotesis (Tabel 6).

Tabel 6. Hasil Uji Hipotesis

\begin{tabular}{lccc}
\hline & Coefficient & p-value & Keterangan \\
\hline DER $\rightarrow$ DA & 0,287 & 0,213 & $\mathrm{Ha}_{1}$ tidak diterima \\
UP $\rightarrow$ DA & $-0,121$ & 0,027 & $\mathrm{Ha}_{2}$ diterima \\
UP $\rightarrow$ CSR & 0,572 & 0,000 & $\mathrm{Ha}_{3}$ diterima \\
CSR $\rightarrow$ DA & $-0,036$ & 0,558 & $\mathrm{Ha}_{4}$ tidak diterima \\
UP $\rightarrow$ CSR $\rightarrow$ DA & $-0,021$ & 0,563 & $\mathrm{Ha}_{5}$ tidak diterima \\
\hline
\end{tabular}

Koefisien regresi leverage (DER) terhadap manajemen laba (DA) adalah positif sebesar 0,287. Jika dilihat dari $p$-value, nilai $p$-value sebesar 0,213 dimana nilai ini $>$ dari 0,05 . Artinya hipotesis pertama tidak diterima dan leverage tidak memiliki efek positif pada manajemen laba. Koefisien regresi besaran perusahaan (UP) terhadap manajemen laba (DA) adalah negatif sebesar -0,121. Jika dilihat dari $p$-value, nilai $p$-value sebesar 0,027 dimana nilai ini < dari 0,05 artinya hipotesis kedua diterima dan besaran perusahaan memiliki efek negatif pada manajemen laba. Koefisien regresi besaran perusahaan (UP) terhadap pengungkapan corporate social responsibility (CSR) adalah positif sebesar 0,572. Jika dilihat dari p-value, nilai $p$-value sebesar 0,000 dimana nilai ini $<$ dari 0,05 artinya hipotesis ketiga diterima dan besaran perusahaan memiliki efek positif ke pengungkapan social responsibility. Koefisien regresi pengungkapan social responsibility (CSR) terhadap manajemen laba (DA) adalah negatif sebesar -0,036. Jika dilihat dari $p$-value, nilai $p$-value sebesar 0,558 dimana nilai ini > dari 0,05 artinya hipotesis keempat tidak diterima dan pengungkapan social responsibility tidak memiliki efek negatif ke manajemen laba. Analisis mediasi pada suatu model penelitian dapat dilakukan dengan melakukan uji terhadap nilai indirect effect variabel eksogen terhadap variabel endogen melalui variabel mediasi. Analisis terhadap indirect effect dilihat dari hasil olah data specific indirect effect. Nilai p-values yang didapatkan dari hasil pengujian harus < dari tingkat signifikansi yang telah ditentukan yaitu sebesar 0,05 . Jika nilai $p$ values > 0,05 maka dapat dikatakan bahwa variabel mediasi tidak dapat memediasi hubungan antara variabel eksogen dan variabel endogen. Hasil penelitian menunjukkan nilai $p$-value sebesar 0,563 . Nilai ini $>$ dari 0,05 artinya hipotesis kelima tidak diterima dan pengungkapan social responsibility tidak dapat memediasi efek besaran perusahaan pada manajemen laba.

Pembahasan. Leverage tidak memiliki efek positif pada manajemen laba. Penelitian ini konsisten dengan (Puspitosari, 2015) namun tidak konsisten dengan (Aissyah et al., 2020) 
serta (Alexander dan Palupi, 2020) yang menunjukkan bahwa leverage memiliki efek positif pada manajemen laba. Penelitian ini hasilnya tidak konsisten pula dengan (Wilson dan Prasetyo, 2020) yang menunjukkan bahwa leverage memiliki efek negatif pada manajemen laba serta (Putriana et al., 2018) yang menunjukkan bahwa leverage tidak memiliki efek negatif pada manajemen laba. Semakin tinggi leverage maka perusahaan memunyai risiko dalam membayar hutang ke pihak kreditur dan risiko yang dihadapi oleh pihak investor juga semakin tinggi. Tentunya pihak kreditur berharap perusahaan dapat mengembalikan hutang. Pihak investor berharap peningkatan leverage akan meningkatkan keuntungan yang didapat. Untuk menjaga kepercayaan para kreditur dan memenuhi harapan para investor, pihak manajemen biasanya melakukan manajemen laba. Hasil penelitian ternyata membuktikan bahwa walaupun perusahaan memiliki leverage yang tinggi, belum tentu perusahaan melakukan manajemen laba. Demikian pula sebaliknya, apabila perusahaan memiliki leverage yang rendah, bisa saja perusahaan tetap melakukan manajemen laba. Hal ini disebabkan leverage bukan faktor yang menyebabkan munculnya manajemen laba karena perusahaan tetap memiliki kewajiban untuk melakukan pembayaran hutang entah manajemen laba dilakukan atau tidak oleh perusahaan. Leverage yang tinggi juga memungkinkan kreditur mengontrol perusahaan sehingga kecil kemungkinan perusahaan melakukan manajemen laba. Di samping itu, leverage yang tinggi menunjukkan kepercayaan kreditur terhadap perusahaan termasuk dalam hal pelunasan hutang. Untuk menjaga kepercayaan tersebut, perusahaan akan menghindari manajemen laba serta menyajikan laporan keuangan yang lebih akurat serta bisa dipercaya.

Besaran perusahaan memiliki efek negatif pada manajemen laba. Penelitian ini konsisten dengan (Gayatri dan Pria, 2016) serta (Halim et al., 2020) tetapi tidak konsisten dengan (Puspitosari, 2015), (Bassiouny, 2016), dan (Surya, 2018) yang menunjukkan bahwa besaran perusahaan tidak memiliki efek negatif pada manajemen laba. Penelitian ini hasilnya tidak konsisten pula dengan (Uwuigbe et al., 2015), dan (Aissyah et al., 2020) yang menunjukkan bahwa besaran perusahaan memiliki efek positif pada manajemen laba serta (Alexander dan Palupi, 2020), serta (Wilson dan Prasetyo, 2020) yang menunjukkan bahwa besaran perusahan tidak memiliki efek positif pada manajemen laba. Penelitian membuktikan besaran perusahaan memiliki efek pada manajemen laba dengan hubungan berbanding terbalik. Ukuran perusahaan yang besar memiliki kegiatan operasional yang lebih kompleks dan luas dibandingkan dengan perusahaan dengan ukuran kecil. Perusahaan besar juga mempunyai stakeholder yang lebih banyak dan kritis dibandingkan dengan perusahaan kecil. Kondisi ini tentunya menyebabkan perusahaan berukuran besar mendapatkan atensi lebih banyak dari masyarakat. Untuk menjaga kepercayaan masyarakat, perusahaan akan berusaha menjaga kestabilan kinerja dan kondisi keuangan perusahaan. Akibatnya tekanan untuk menyajikan laporan keuangan yang akurat dan dapat dipercaya juga lebih besar dibandingkan dengan perusahaan kecil. Perusahaan besar akan lebih berhati-hati dalam menyajikan laporan keuangan dan meminimalkan tindakan manajemen laba. Demikian pula sebaliknya, perusahaan berukuran kecil lebih memiliki potensi untuk melakukan manajemen laba guna menunjukkan kinerja dan kondisi keuangan yang lebih baik.

Besaran perusahaan memiliki efek positif pada pengungkapan social responsibility. Penelitian ini konsisten dengan (Gayatri dan Pria, 2016), (Sumaryono dan Asyik, 2017), 
(Erawati et al., 2018), (Surya, 2018), dan (Aziz et al., 2021) tetapi tidak konsisten dengan (Zulhaimi dan Nuraprianti, 2019) yang menunjukkan bahwa besaran perusahaan tidak memiliki efek positif pada pengungkapan social responsibility. Penelitian ini hasilnya tidak konsisten pula dengan (Yunina dan Eftiana, 2017) yang menunjukkan bahwa besaran perusahaan memiliki efek negatif pada pengungkapan social responsibility serta (Saragih dan Sembiring, 2019) serta (Kurniawan dan Yuniarta, 2020) yang menunjukkan bahwa besaran perusahan tidak memiliki efek negatif pada pengungkapan social responsibility. Penelitian membuktikan besaran perusahaan memiliki efek pada pengungkapan social responsibility dengan hubungan berbanding lurus. Perusahaan dengan ukuran besar memiliki biaya politis dan biaya keagenan yang lebih besar dibandingkan perusahaan dengan ukuran kecil. Salah satu usaha untuk meminimalkan biaya politis dan biaya keagenan adalah dengan melakukan pengungkapan social responsibility secara lebih luas. Luasnya pengungkapan informasi dalam laporan tahunan ditentukan oleh ukuran perusahaan. Perusahaan besar mempunyai sumber daya yang lebih besar, kegiatan operasional yang lebih luas dan kompleks, jumlah stakeholder yang lebih banyak, kontrol yang lebih besar terhadap kondisi pasar (kemampuan bersaing), dan perhatian atau sorotan lebih dari masyarakat dibanding dengan perusahaan kecil. Artinya perusahaan besar mempunyai tekanan lebih untuk mengungkapkan informasi kepada para stakeholder dibandingkan dengan perusahaan kecil. Perusahaan menganggap cara yang paling efisien untuk menyampaikan informasi ke para stakeholder mengenai aktivitas perusahaan adalah dengan mengungkapkan social responsibility seluas mungkin.

Pengungkapan social responsibility tidak memiliki efek negatif pada manajemen laba. Penelitian ini memiliki hasil yang konsisten dengan (Alexander dan Palupi, 2020) namun tidak konsisten dengan (Gayatri dan Pria, 2016) yang menunjukkan bahwa pengungkapan social responsibility memiliki efek negatif pada manajemen laba. Penelitian ini hasilnya tidak konsisten juga dengan (Mahrani dan Soewarno, 2018), serta (Halim et al., 2020) yang menunjukkan bahwa pengungkapan social responsibility memiliki efek positif pada manajemen laba serta (Putriana et al., 2018), (Surya, 2018), dan (Kalbuana et al., 2020) yang menunjukkan bahwa pengungkapan social responsibility tidak memiliki efek positif pada manajemen laba. Untuk dapat mempertahankan hubungan hubungan jangka panjang dengan para stakeholder, perusahaan biasanya akan mengungkapkan social responsibility. Harapan perusahaan dengan mengungkapkan social responsibility ialah dapat meningkatkan profitabilitas dan reputasi perusahaan, menjaga legitimasi dari masyarakat dan lingkungan dimana perusahaan beroperasi, serta menjamin keberlangsungan usaha perusahaan. Pengungkapan social responsibility menunjukkan transparansi dalam semua aspek bisnis perusahaan sehingga pihak stakeholder akan menerima informasi lebih banyak mengenai aktivitas perusahaan, mengurangi kemungkinan adanya asimetri informasi, dan meningkatkan kepercayaan para stakeholder terhadap perusahaan. Untuk mempertahankan kepercayaan para stakeholder, maka manajemen akan meminimalkan tindakan manajemen laba. Hasil penelitian ternyata membuktikan bahwa walaupun perusahaan melakukan pengungkapan social responsibility yang luas, manajemen laba tetap saja dilakukan. Motivasi perusahaan melakukan pengungkapan social responsibility ialah guna menutupi manajemen laba yang dilakukan oleh perusahaan. Kegiatan pengungkapan social responsibility menimbulkan biaya yang berdampak pada rendahnya laba periode berjalan. Perusahaan akan melakukan manajemen 
laba dengan memilih metode akuntansi yang dapat meningkatkan laba guna mengelabuhi seolah-olah perusahaan memiliki kinerja dan kondisi keuangan yang baik. Selain itu perusahaan melakukan pengungkapan social responsibility tidak hanya untuk tujuan menutupi tindakan manajemen laba, namun merupakan kewajiban perusahaan untuk mendapatkan legitimasi dari lingkungan dan masyarakat dimana perusahaan beroperasi.

Pengungkapan social responsibility tidak bisa memediasi efek besaran perusahaan pada manajemen laba. Penelitian ini konsisten dengan (Gayatri dan Pria, 2016), serta (Surya, 2018) yang menunjukkan bahwa pengungkapan social responsibility dapat memediasi efek besaran perusahaan pada manajemen laba. Jika besaran perusahaan semakin besar, maka perusahaan akan melakukan pengungkapan social responsibility lebih luas guna memperoleh legitimasi dari lingkungan dan masyarakat dimana perusahaan beroperasi demi perkembangan perusahaan di masa depan. Untuk menjaga legitimasi tersebut, manajemen cenderung meminimalkan tindakan manajemen laba. Penelitian ternyata membuktikan bahwa pengungkapan social responsibility tidak bisa memediasi pengaruh ukuran perusahaan ke manajemen laba. Perusahaan besar tetap akan meminimalkan manajemen laba walaupun perusahaan melakukan pengungkapan social responsibility secara luas atau tidak luas. Hal ini disebabkan pengungkapan social responsibility yang dilakukan oleh perusahaan adalah kewajiban semata guna mendapatkan legitimasi dari lingkungan dan masyarakat dimana perusahaan beroperasi.

\section{KESIMPULAN}

Leverage tidak memiliki efek positif pada manajemen laba. Hal ini dikarenakan leverage bukan faktor yang menyebabkan munculnya manajemen laba. Perusahaan melakukan manajemen laba atau tidak, perusahaan tetap memiliki kewajiban untuk melakukan pembayaran hutang. Leverage yang tinggi memungkinkan kreditur mengontrol perusahaan sehingga kecil kemungkinan perusahaan untuk melakukan manajemen laba. Selain itu leverage yang tinggi menunjukkan kepercayaan kreditur terhadap perusahaan termasuk dalam hal pelunasan hutang. Untuk menjaga kepercayaan tersebut, perusahaan akan menghindari manajemen laba serta menyajikan laporan keuangan yang lebih akurat dan bisa dipercaya.

Besaran perusahaan memiliki efek negative pada manajemen laba. Perusahaan dengan ukuran besar mempunyai kegiatan operasional yang lebih kompleks serta stakeholder yang lebih banyak dan kritis dibandingkan perusahaan dengan ukuran kecil. Kondisi ini tentunya menyebabkan perusahaan berukuran besar mendapatkan atensi lebih banyak dari masyarakat. Untuk menjaga kepercayaan masyarakat, perusahaan akan menyajikan laporan keuangan yang akurat dan dapat dipercaya serta meminimalkan tindakan manajemen laba.

Besaran perusahaan memiliki efek positif pada pengungkapan social responsibility. Perusahaan berukuran besar memiliki sumber daya yang lebih besar, kegiatan operasional yang lebih luas dan kompleks, jumlah stakeholder yang lebih banyak, kontrol yang lebih besar terhadap kondisi pasar (kemampuan bersaing), dan perhatian atau sorotan lebih dari masyarakat dibandingkan dengan perusahaan kecil. Perusahaan besar mempunyai tekanan lebih untuk mengungkapkan informasi kepada para stakeholder dibandingkan dengan perusahaan kecil. Salah satu cara yang dianggap paling efisien oleh perusahaan untuk 
mengurangi biaya politis dan biaya keagenan sekaligus menyampaikan informasi ke para stakeholder mengenai aktivitas perusahaan adalah dengan melakukan pengungkapan social responsibility.

Pengungkapan social responsibility tidak memiliki efek negatif pada manajemen laba. Hal ini dikarenakan tujuan perusahaan melakukan pengungkapan social responsibility adalah guna menutupi manajemen laba yang dilakukan oleh perusahaan. Kegiatan pengungkapan social responsibility menimbulkan biaya yang berdampak pada rendahnya laba periode berjalan sehingga perusahaan akan melakukan manajemen laba guna mengelabuhi seolah-olah perusahaan memiliki kinerja dan kondisi keuangan yang baik. Pengungkapan social responsibility tidak bisa memediasi efek besaran perusahaan pada manajemen laba. Perusahaan besar tetap akan meminimalkan manajemen laba walaupun perusahaan melakukan pengungkapan social responsibility secara luas atau tidak luas. Hal ini disebabkan pengungkapan social responsibility yang dilakukan oleh perusahaan adalah kewajiban semata guna mendapatkan legitimasi dari masyarakat dan lingkungan dimana perusahaan beroperasi.

Keterbatasan dalam penelitian ini ada beberapa. Pertama, peneliti hanya menggunakan variabel leverage dan besaran perusahaan. Untuk penelitian lebih lanjut, sebaiknya menggunakan variabel eksogen lain yang diduga dapat memengaruhi variabel endogen, seperti tata kelola perusahaan. Hal ini dikarenakan untuk meminimalkan tindakan manajemen laba dan menyajikan laporan keuangan yang berkualitas, perusahaan perlu melakukan tata kelola perusahaan yang baik. Kedua, keterbatasan kurun waktu penelitian yaitu hanya selama tahun 2017-2019. Penelitian selanjutnya, sebaiknya menggunakan kurun waktu yang lebih panjang guna menemukan bukti empiris perubahan pola manajemen laba dalam jangka panjang. Ketiga, penelitian ini menggunakan model (Kothari et al., 2005) dalam mengukur manajemen laba. Untuk penelitian berikutnya, sebaiknya menggunakan model pengukuran manajemen laba yang berbeda seperti model pendekatan baru (Dechow et al., 2012) guna mengurangi kesalahan dalam menghitung diskresioner akrual.

\section{DAFTAR PUSTAKA}

Ahmar, N., Rokhmania, N., dan Samekto A. (2016). Model Manajemen Laba Akrual dan Riil Berbasis Implementasi International Financial Reporting Standards. Jurnal Akuntansi dan Investasi, 17(1), 79-92. http://dx.doi.org/10.18196/jai.2016.0046.79$\underline{92}$.

Aissyah, N. N. A., Nurlaela, S., dan Samrotun, Y. C. (2020). Kepemilikan Manajerial, Leverage, Profitabilitas, Ukuran Perusahaan dan Manajemen Laba Pada Perusahaan

Properti dan Real Estate. Jurnal Penelitian Ekonomi dan Akuntansi, 5(1), 49-61.

Alexander, N., dan Palupi, A. (2020). Pengaruh Corporate Social Responsibility Reporting Terhadap Manajemen Laba. Jurnal Bisnis dan Akuntansi, 22(1), 105-112.

Apriyani, R. dan Pasaribu, R. B. (2015). Earning Management dan Relevansi Informasi Akuntansi: Pendekatan Motivasi Signaling dan Oportunistik. Prosiding PESAT (Psikologi, Ekonomi, Sastra, Arsitektur, dan Teknik Sipil), 6, 529-537. http://dx.doi.org/10.13140/RG.2.1.5054.6647. 
Arowoshegbe, A. O., and Emmanuel, U. (2016). Sustainability and Triple Bottom Line: An Overview of Two Interrelated Concepts. Igbinedion University Journal of Accounting, 2, 88-126.

Astuti, A. Y., Nuraina, E., dan Wijaya, A. L. (2017). Pengaruh Ukuran Perusahaan dan Leverage Terhadap Manajemen Laba. FIPA: Forum Ilmiah Pendidikan Akuntansi, 5(1), 501-515.

Aziz, R., Askandar, N. S., dan Sudaryanti, D. (2021). Pengaruh Ukuran Perusahaan, Kinerja Keuangan, Financial Leverage dan Manajemen Laba Terhadap Pengungkapan Corporate Social Responsibility Pada Perusahaan Manufaktur Yang Terdaftar di BEI 2016-2018. e-Jurnal Ilmiah Riset Akuntansi, 10(4), 1-15.

Bassiouny, S. W. (2016). The Impact of Firm Characteristics on Earnings Management: An Empirical Study on The Listed Firms in Egypt. Journal of Business and Retail Management Research, 10(3), 34-45.

Dechow, P. M., Hutton, A. P., Kim, J. H., and Sloan, R. G. (2012). Detecting Earnings Management: A New Approach. Journal of Accounting Research, 50(2), 275-334. http://dx.doi.org/10.1111/j.1475-679X.2012.00449.x.

Erawati, T., Ayem, S., dan Ayudiyati, P. (2018). Pengaruh Ukuran Perusahaan Terhadap Pengungkapan Corporate Social Responsibility Dengan Profitabilitas Sebagai Variabel Moderating Pada Perusahaan Manufaktur Yang Terdaftar di Bursa Efek Indonesia Tahun 2012-2016. Jurnal Riset Akuntansi, 3(1), 136-159.

Freeman, R. E., and McVea, J. (2001). A Stakeholder Approach to Strategic Management Working Paper No. 01-02. Darden Graduate School of Business Administration University of Virginia. http://dx.doi.org/10.2139/ssrn.263511.

Gayatri, dan Pria, P. (2016). Implikasi Ukuran Perusahaan dan Pengungkapan Corporate Social Responsibility Terhadap Manajemen Laba. Jurnal Riset Akuntansi, 6(4), 1-22.

Ghazali, A. W., Shafie, N. A., and Sanusi, Z. M. (2015). Earnings Management: An Analysis of Opportunistic Behaviour, Monitoring Mechanism and Financial Distress. Procedia Economics and Finance, 28, 190-201. https://doi.org/10.1016/S22125671(15)01100-4.

Guthrie, J., Cuganesan, S., and Ward, L. (2006). Legitimacy Theory: A Story of Reporting Social and Environmental Matters Within the Australian Food and Beverage Industry, 1-35.

Halim, S. A., Gani, P., Siregar, H., dan Fajrillah. (2020). Pengaruh Good Corporate Governance, Corporate Social Responsibility, dan Ukuran Perusahaan Terhadap Manajemen Laba. Terapan Informatika Nusantara, 1(4), 163-170.

Jensen, M. C., and Meckling, W. H. (1976). Theory of The Firm: Managerial Behavior, Agency Costs and Ownership Structure. Journal of Financial Economics, 3, 305360.

Kalbuana, N., Utami, S., dan Pratama, A. (2020). Pengaruh Pengungkapan Corporate Social Responsibility, Persistensi Laba dan Pertumbuhan Laba Terhadap Manajemen Laba Pada Perusahaan Yang Terdaftar di Jakarta Islamic Index. Jurnal Ilmiah Ekonomi Islam, 6(2), 350-358.

Kothari, S. P., Leone, A. J., and Wasley, C. E. (2005). Performance Matched Discretionary Accrual Measures. Journal of Accounting and Economics, 39(1), 163-197. https://doi.org/10.1016/j.jacceco.2004.11.002. 
Kurniawan, K. A., dan Yuniarta, G. A. (2020). Pengaruh Profitabilitas, Ukuran Perusahaan, Likuiditas, dan Risk Minimization Terhadap Pengungkapan Corporate Social Responsibility. Jurnal Akuntansi Profesi, 11(1), 12-23.

Lindawati, A. S. L., dan Puspita, M. E. (2015). Corporate Social Responsibility: Implikasi Stakeholder dan Legitimacy Gap Dalam Peningkatan Kinerja Perusahaan. Jurnal Akuntansi Multiparadigma, 6(1), 157-174.

Mahrani, M., and Soewarno, N. (2018). The Effect of Good Corporate Governance Mechanism and Corporate Social Responsibility on Financial Performance with Earnings Management as Mediating Variable. Asian Journal of Accounting Research, 3(1), 41-60.

Nurhandono, F., dan Firmansyah, A. (2017). Lindung Nilai, Financial Leverage, Manajemen Laba dan Agresivitas Pajak. Jurnal Media Riset Akuntansi, Auditing \& Informasi, 17(1), 31-52.

Pambudi, J. E. (2017). Pengaruh Kepemilikan Manajerial dan Debt Covenant Terhadap Konservatisme Akuntansi. Competitive, 1(1), 87-110.

Panjaitan, D. K., dan Muslih, M. (2019). Manajemen Laba: Ukuran Perusahaan, Kepemilikan Manajerial dan Kompensasi Bonus. Jurnal Aset (Akuntansi Riset), 11(1), 1-20.

Parmar, B. L. Freeman, R. E., Harrison, J. S., Wicks, A. C., Colle, S., and Purnell L. (2010). Stakeholder Theory: The State of the Art. The Academy of Management Annals, 4(1), 403-445. https://doi.org/10.1080/19416520.2010.495581.

Purnama, D. (2017). Pengaruh Profitabilitas, Leverage, Ukuran Perusahaan, Kepemilikan Institusional dan Kepemilikan Manajerial Terhadap Manajemen Laba. Jurnal Riset Keuangan dan Akuntansi, 3(1), 1-14.

Puspitosari, L. (2015). Analisis Faktor-Faktor Yang Berpengaruh Terhadap Manajemen Laba Pada Perbankan Syariah Periode 2010-2013. Jurnal MIX, 6(2), 260-274.

Putriana, M., Artati, S., dan Utami, V. J. (2018). Pengaruh Corporate Social Responsibility Terhadap Manajemen Laba Dengan Leverage dan Growth Sebagai Variabel Control Pada Industri Farmasi Yang Terdaftar di Bursa Efek Indonesia. Jurnal Manajemen dan Sains, 3(2), 226-236.

Rahmawardani, D. D., dan Muslichah. (2020). Corporate Social Responsibility Terhadap Manajemen Laba dan Kinerja Perusahaan. Jurnal Riset Akuntansi Kontemporer, 12(2), 52-59.

Ricardo, D. M., dan Faisal. (2015). Pengaruh Pengungkapan Corporate Social Responsibility Terhadap Praktik Manajemen Laba. Diponegoro Journal of Accounting, 4(3), 1-9.

Saragih, A. E., dan Sembiring, Y. C. B. (2019). Pengaruh Corporate Governance, Profitabilitas, Leverage, dan Ukuran Perusahaan Terhadap Pengungkapan Corporate Social Responsibility Pada Perusahaan Industri Dasar dan Kimia Yang Terdaftar di BEI. Jurnal Riset Akuntansi dan Keuangan, 5(2), 139-164.

Sumaryono, A., dan Asyik, N. F. (2017). Pengaruh Size, Profitabilitas dan Leverage Terhadap Pengungkapan Corporate Social Responsibility. Jurnal Ilmu dan Riset Akuntansi, 6(8), 1-17.

Surya, S. (2018). Apakah Perusahaan Skala Besar Melakukan Manajemen Laba? Studi Empiris Pada Industri Tambang di Indonesia. National Conference of Creative 
Industry: Sustainable Tourism Industry for Economic Development, Universitas Bunda Mulia, September 5-6, Jakarta.

Suyono, E. (2017). Bebagai Model Pengukuran Earnings Management: Mana Yang Paling Akurat. Sustainable Competitive Advantage, 7, 303-324.

Tan, M., dan Hadi, S. (2020). Effect of CR, DER, TATO, and Firm Size on Profitability in Pharmaceutical Companies Listed on IDX. Kurs: Jurnal Akuntansi, Kewirausahaan, dan Bisnis, 5(1), 58-69.

Trijaya, W., dan Riswandari, E. (2017). Pengaruh Ukuran Perusahaan, Umur Perusahaan dan Pengungkapan Media Terhadap Pengungkapan Corporate Social Responsibility (CSRD). WAHANA, 20(2), 28-37.

Uwuigbe, U., Uwuigbe, O. R., and Bernard, O. (2015). Assessment of The Effects of Firms' Characteristics on Earnings Management of Listed Firms in Nigeria. Asian Economic and Financial Review, 5(2), 218-228.

Wilson, dan Prasetyo, A. (2020). Pengaruh Mekanisme Good Corporate Governance, Leverage, dan Ukuran Perusahaan Terhadap Manajemen Laba (Studi Empiris Pada Perusahaan Kategori Indeks Sri-Kehati Yang Terdaftar Dalam Bursa Efek Indonesia Periode 2013-2017). Akuntansi Keuangan, 9(1), 59-72.

Wufron. (2017). Pengaruh Ukuran Perusahaan Terhadap Kinerja Keuangan Serta Implikasinya Terhadap Nilai Perusahaan Pada Perusahaan Manufaktur Yang Terdaftar di Bursa Efek Indonesia. Jurnal Wacana Ekonomi, 16(3), 22-33.

Yunina, dan Eftiana, N. (2017). Pengaruh Ukuran Perusahaan, Ukuran Dewan Komisaris dan Sensitivitas Industri Terhadap Pengungkapan Corporate Social Responsibility Pada Perusahaan LQ-45 Yang Terdaftar di BEI Tahun 2014-2016. Jurnal Akuntansi dan Keuangan, 5(2), 119-135.

Zulhaimi, H., dan Nuraprianti, N. R. (2019). Pengaruh Profitabilitas, Ukuran Dewan Komisaris, dan Ukuran Perusahaan Terhadap Corporate Social Responsibility Disclosure. Jurnal Riset Akuntansi dan Keuangan, 7(3), 555-566. 